\title{
Pojęcie „pomocy społecznej” w kontekście godności i autonomii osoby bezdomnej (aspekty filozoficzne i prawne)
}

\author{
Anetta Breczko*, Alina Miruć**
}

\begin{abstract}
Streszczenie: Pomoc społeczna jest instytucją życia społecznego, której prawidłowe funkcjonowanie determinują nie tylko ramy obowiązującego prawa, ale również normy różnych systemów pozaprawnych (głównie systemu moralnego). Celem niniejszego artykułu stała się analiza pojęcia „pomocy społecznej" w kontekście godności oraz autonomii osoby bezdomnej, zarówno z perspektywy aksjologicznej, jak i prawnej. W opracowaniu zastosowano w szczególności metodę dogmatyczną. Perspektywa filozoficzna ukazuje, że pojęcie "pomocy" jest wieloznaczne i nie zawsze wiąże się z pozytywnym ładunkiem aksjologicznym. W ujęciu prawnym fundamentalnymi przesłankami "dobrego administrowania" oraz faktycznego zapewnienia bezpieczeństwa socjalnego osobom potrzebującym (w tym bezdomnym) są: godność osobowa i godność osobista, powiązane z koniecznością respektowania autonomii człowieka. Prawo pomocy społecznej, które nie uwzględnia tych wartości, nie może być ocenione jako "dobre”.
\end{abstract}

Słowa kluczowe: bezdomny, godność, autonomia, aksjologia, pomoc społeczna.

\section{Wprowadzenie}

Pomoc społeczna jest zarówno obowiązkiem prawnym, ciążącym na kompetentnych podmiotach władzy publicznej, jak również powinnością moralną, wynikającą z ukształtowanej pod wpływem antropologii chrześcijańskiej "etyki miłości”. Jej kluczowym aksjomatem stało się "miłosierdzie” powiązane z motywowanym altruizmem wsparciem dla tych, którzy pomocy oczekują. Takie ujęcie istoty „pomagania” - ugruntowane w europejskim kręgu kulturowym - wiąże się z ujmowaniem "dobrego człowieka” jako podmiotu, który urealnia normatywny model „dobrego Samarytanina”. Biorąc pod uwagę naukowe ustalenia, pozbawione religijnej proweniencji, z istotą pomagania wiążą nie tyle powody niesienia pomocy (altruistyczne bądź egoistyczne), ale przede wszystkim konsekwencje „pomocowych” działań. Tym niemniej, etyczna polisemiczność pojęcia „pomocy” prowokuje do wielu pytań. Oto kilka z nich: czy „pomaganie” innym jest zawsze bezwzględną moralną powinnością? czy każda pomoc jest "dobra" w sensie moralnym? co określa granice moralnego obowiązku pomagania? kiedy bezwzględnie nie należy pomagać? czy komukolwiek wolno

\footnotetext{
* Anetta Breczko

Katedra Teorii Prawa i Filozofii Prawa, Wydział Prawa Uniwersytet w Białymstoku

ul. M. Skłodowskiej-Curie 14, 15-097 Białystok

e-mail:breczko@uwb.edu.pl

** Alina Miruć

Wydział Ochrony Zdrowia

Państwowa Wyższa Szkoła Zawodowa

im. prof. Edwarda F. Szczepanika w Suwałkach

ul. T. Noniewicza 10, 16-402 Suwałki

e-mail:a.miruc@wp.pl
} 
zabronić być osobą bezdomną, jeśli taka jest jego wola? czy władza może ograniczyć autonomię człowieka bezdomnego, zmuszając go do zamieszkania w lokalu socjalnym w imię zapewnienia mu godnego życia?

Wydaje się, że to głównie doktryna prawnicza zobligowana jest do udzielenia stosownych odpowiedzi na postawione wyżej pytania. Odpowiedzi te mają stanowić swoisty „drogowskaz" w procesie tworzenia oraz stosowania prawa. Aksjologia nie może być pominięta przy próbie rozstrzygnięć prawnych w tym zakresie.

Z perspektywy prawa kluczowe okazuje się ustalenie, jaka jest istota pojęcia „pomocy społecznej" w polskim prawodawstwie i praktyce orzeczniczej. Niezwykle ważne staje się uwzględnienie godności (we wszystkich jej wymiarach) jako podstawy „dobrego administrowania" oraz condition sine qua non zapewnienia bezpieczeństwa socjalnego. To właśnie godność w powiązaniu z autonomią podmiotów prawa pomocy społecznej staje się podstawą do prawnego określenia pojęcia "osoby bezdomnej” oraz „bezdomności" jako przesłanek do udzielania pomocy społecznej w polskim systemie prawnym.

\section{Polisemiczność pojęcia „pomocy” - perspektywa aksjologiczna}

Encyklopedyczne i słownikowe definicje pojęcia pomocy są właściwie aksjologicznie neutralne. „Pomoc” oznacza wspieranie kogoś - dzięki odpowiednim środkom - tak, by osiągnął on zamierzony cel. Ujmowana jest jako podejmowanie jakiegoś wysiłku dla dobra innej osoby w celu ulżenia jej w czymś lub poratowania w trudnej sytuacji. Takie definicje obejmują działania, które mogą być dobre lub złe, ale mogą być też indyferentne moralnie.

Znaczenie idei pomocy zarówno w filozofii, etyce, jak i życiu społecznym wiąże się głównie z jej pozytywnym wydźwiękiem. Widoczne jest przy tym jej wyraźnie „uwikła- nie" w świat wartości moralnych. Od wieków świadczenie pomocy traktowane było jako altruistyczne działanie na rzecz innych. Stało się wyróżnikiem i podstawowym obowiązkiem moralnym „dobrego człowieka" [Kusak, 2012, s. 11-30].

Zaangażowanymi i wpływowymi orędownikami idei pomocy były (i nadal są) przeróżne monoteistyczne religie, z chrześcijaństwem na czele. Promują one postawę współczucia i miłosierdzia, odwołując się do osobistego przykładu życia proroków bądź też do prawa ustanowionego przez Boga, objawionego ludziom za ich pośrednictwem w świętych księgach. I niezależnie od tego, czy czytamy Pismo Święte czy Koran, i tu i tam są nakazy, by nie odwracać się od ubogich, bo wtedy Bóg nie odwróci się od nas.

Związek między miłosierdziem, dobrymi uczynkami i zbawieniem dobitnie potwierdza przywoływana nieraz przypowieść o miłosiernym Samarytaninie. W religii chrześcijańskiej kluczowym punktem odniesienia do obowiązku pomocy jest „przykazanie miłości" (Miłuj bliźniego swego jak siebie samego). To właśnie na gruncie tego przykazania wyrosła „etyka miłości” budowana przez przedstawicieli antropologii chrześcijańskiej. Miłość w takim ujmowaniu jest na wskroś altruistyczna. Polega na tym, że litujemy się nad losem bliźniego, współczujemy mu i pomagamy w duchu miłosierdzia. Credo chrześcijańskie daje się właściwie sprowadzić do - jak to ujęła Matka Teresa z Kalkuty dwóch kluczowych słów: „miłość” i „miłosierdzie" [Księga aforyzmów, 2008, s. 134].

Nie można jednak zapominać o tym, że do altruistycznie pojmowanej miłości bliźniego krytycznie odnosi się wielu filozofów. Prawomocność uzasadnienia norm nakazujących dobroczynność przez odwoływanie się do autorytetu Boga zakwestionował w sposób wyrazisty F. Nietzsche. Przyjmował on, że Bóg jest tylko hipostazą, wytworem człowieka słabego, który nie znajduje w sobie dość siły, by stawić czoło życiu na własnych warunkach. 
Filozof ten twierdził, że nie ma pomocy bezinteresownej, bo człowiek nigdy nie czyni czegoś wyłącznie dla innych, bezżadnej pobudki osobistej. Jakże by „ego" mogło działać bez „ego"? - pytał retorycznie. Jego zdaniem za altruistycznymi postępkami zawsze kryją się egoistyczne intencje, które niweczą ich pozytywną wartość. „Dobroczynność”, „pomaganie", „współczucie dla cierpiącego i potrzebującego pomocy" tracą swój powab i moralne walory, bo człowiek poprzez nie zaspakaja podstawowy dla gatunku ludzkiego popęd: "wolę mocy". Dzięki nim pozbywa się dyskomfortu psychicznego, który dotyka go niemile, gdy patrzy na nieszczęścia i cierpienia innych. Są one przecież oznaką ułomności i niedołęstwa gatunku ludzkiego. Współczucie może się również wiązać z doznawaniem pozytywnych odczuć (swoistej wręcz rokoszy), które wywołuje w człowieku poczucie własnego „wyższego" położenia. Nietzsche zauważał, że symptomem współczesnych czasów (czasów „ludzi słabych") jest "grasująca moralność litości". To swoista moda, która pod presją opinii publicznej zmusza ludzi do pomagania bez względu na okoliczności; pomimo braku woli niesienia pomocy [Nietzsche, 2010; idem, 2003].

Poglądy Nietzschego nie są odosobnione. Psychologiczny hedonizm zakłada przykładowo, że ludzie dążą w swoim życiu do przyjemności i za wszelką cenę starają się unikać cierpienia. Badania z zakresu neurologii i kognitywistyki ukazują, że gdy człowiek działa na rzecz innych aktywizują się obszary kory mózgowej, które związane są z przyjemnością. W biologii ewolucyjnej zyskały popularność teorie: „selekcji krewniaczej” i „odwzajemnienia” [Kusak, 2012, s. 22]. Pierwsza z nich wiąże się z założeniem, że jeśli adresatami pomocy są krewni, to dla altruisty jest ona opłacalna, gdyż sprzyja rozpowszechnieniu jego genów w następnym pokoleniu. Druga natomiast zakłada, że akt altruizmu kierowany do kogoś obcego może przynieść korzyści altruiście, bo w przyszłości będzie najpewniej odwzajemniony. $\mathrm{Na}$ gruncie socjobiologii i bioetyki środowiskowej przyjmuje się, że dla istot żywych wszelkie cechy zachowania, w tym skłonność do działań altruistycznych, powstały w toku ewolucji na drodze doboru naturalnego i są zdeterminowane genetycznie [Wilson, 1998]. Wskazuje się przy tym, że ewolucja biologiczna została uzupełniona ewolucją kulturową. Dobór krewniaczy doprowadził do powstania altruizmu określonego jako "altruizm twardy" (wiązany z naturalną skłonnością do pomocy członkom rodziny). Pod wpływem uwarunkowań kulturowych wykształcił się też tzw. „altruizm miękki”, który jest efektem doboru indywidualnego i stanowi właściwie wyrafinowaną formę samolubstwa. Szlachetne zachowanie wiąże się bowiem z nadzieją, że społeczeństwo odpłaci nam za wyrządzone przez nas dobro.

Z perspektywy współczesnej antropologii filozoficznej wielowiekowa dominacja stylu życia, w ramach którego wysoko ceni się altruizm (współczucie, miłosierdzie), nie jest kwestią arbitralnego wyboru jednostki, lecz „odpowiedzią" dostosowaną do wyzwań przed jakimi stał i wciąż stoi gatunek homo sapiens w toku swej biologicznej i kulturowej ewolucji [Kusak, 2012, s. 27]. Postawy nacechowane życzliwością wobec innych, dostrzeganie i docenianie cudzych potrzeb, gotowość świadczenia pomocy analizowane $z$ antropologicznego i etycznego punktu widzenia - przyczyniają się do tworzenia się podstawowych atrybutów gatunku ludzkiego, jego przetrwania i rozwoju. Społecznej akceptacji zachowań, których celem jest dobro drugiego człowieka sprzyja fakt, że tego typu działania są zgodne z ludzką naturą. Oprócz bowiem skłonności do zabiegania o własne, egoistyczne i wąsko rozumiane dobro, człowiekowi właściwe jest także dążenie do dobra wspólnego. Jednostka znajduje w nich sens swojej egzystencji i spełnia się jako człowiek. 
Przyglądając się filozoficznej dyskusji dotyczącej samych motywów niesienia pomocy, można skonstatować, że pobudki, którymi kierują się ludzie pomagając innym nie są właściwie istotne. Liczy się bowiem przede wszystkim efektywność określonego działania.

Podkreślić należy, że pojęcie "pomocy” wypracowane na gruncie kultury europejskiej, pozostającej pod niewątpliwym wpływem chrześcijańskiej "etyki miłości”, ma najczęściej pozytywne konotacje etyczne. „Pomaganie" uznawane jest za powszechnie oczekiwany element współczesnego świata wartości.

Jednak nie każda pomoc może być uznana za działanie "dobre” w sensie moralnym. Pomoc nielegalna, pochopna, nieuzasadniona albo naruszająca fundamentalne wartości (takie jak: godność, sprawiedliwość, wolność etc.) musi zostać oceniona jednoznacznie negatywnie. Tego typu pomoc, choć rzadko, to jednak pojawia się w praktyce. W tym kontekście konieczna staje się odpowiedź na pytanie: czy „pomaganie” innym jest zawsze bezwzględną moralną powinnością?

W rozważaniach doktrynalnych kluczowa stała się teza, że nie należy pomagać, gdy pomoc kłóci się z ideą godności. Jest to niedopuszczalne nawet wówczas, gdy „pomagający" uwzględnia wolę i autonomię osoby potrzebującej pomocy, która wręcz prosi o naruszenie swojej własnej godności osobowej. Zobrazować to można na przykładzie, oderwanym wprawdzie od zasadniczej problematyki naszego opracowania, jednak bardzo dobrze oddającym istotę sprawy. W wielu państwach odbywają się nielegalne zawody o wiele mówiącej nazwie: „rzut karłem na odległość". Człowiek niskiego wzrostu, występując w roli przedmiotu, ma być jak najdalej rzucany przez zawodników. Karzeł sam zgłasza się do organizatorów takich konkurencji skuszony pieniędzmi, które ma w zamian otrzymać. Z jednej strony autono- miczny, wolny podmiot chce, aby go potraktowano przedmiotowo, z drugiej zaś są tacy, którzy mogą mu "pomóc" w realizacji jego woli. Niemiecki sąd nie miał wątpliwości, że skoro godność jest niezbywalna, to w powyższej sytuacji nie można jej nikomu (w tym przypadku karłowi) odebrać, nawet za jego zgodą [Sadowski, 2007, s. 8-28]. Należy się jednak zastanowić, co byłoby w przypadku, gdyby podobna konkurencja dotyczyła ludzi normalnego wzrostu? Czy na powyższe orzeczenie nie wpłynęły w zbyt istotnym stopniu założenia „politycznej poprawności”? Czy człowiekowi w ogóle można dziś zabronić instrumentalnego wykorzystywania samego siebie, chociażby dla ekstremalnych doznań? Idąc dalej tym tropem myślenia możemy zapytać: czy komukolwiek wolno zakazać być osobą biedną albo bezdomną, jeśli taka jest jej wola?

Z pespektywy wypracowanych na gruncie etyki ogólnej standardów godność osobowa stanowi wartość ontyczną, przyrodzoną ludziom; wartość, z której nie można skutecznie zrezygnować. Trafnie odzwierciedla ją maksyma stoików: homo homini res sacra. Godność to swoista "bezcenność" [Kant, 1953, s. 70]. To również: „odmowa wyłączenia człowieczeństwa w człowieku nawet za jego zgodą" [Pavia, 2001, s. 135].

Przyjęcie godności osobowej jako „prewartości", a więc wartości, z której wywodzą się wszystkie inne wartości i normy, pociąga za sobą konieczność uznania wolności i autonomii człowieka. Respektowanie godności wymaga traktowania ludzi jako osób zdolnych do planowania i projektowania swojej przyszłości [Raz, 2000, s. 211]. Zgodnie z przyjętą w demokratycznych państwach zasadą domniemania wolności jednostka musi mieć zagwarantowaną możliwość swobodnego poruszania się w sferze indyferencji prawnej, a więc pomiędzy nakazami i zakazami prawa. Może podejmować autonomiczne decyzje i wybory kierując się własnym światopoglądem, religią, preferowanym stylem 
życia itp. Aby się swobodnie rozwijać, człowiek potrzebuje wielu dóbr, m.in. mieszkania, które zapewnia mu realizację podstawowej potrzeby bezpieczeństwa.

Czy zatem władza może ograniczyć autonomię człowieka bezdomnego, zmuszając go do zamieszkania w lokalu socjalnym w imię zapewnienia mu godnego życia? Godność osobowa przynależna każdemu człowiekowi z mocy prawa, także osobom bezdomnym (i wszystkim innym funkcjonującym w sferze wykluczenia społecznego), nie może być naruszona poprzez nadmierne, nieuzasadnione ingerencje $\mathrm{w}$ prawo do prywatności oraz prawo do decydowania o własnym życiu (prawo do samostanowienia). Bezdomność, wprawdzie rzadko, ale jednak bywa świadomym wyborem, stylem życia, który chociaż nie jest ani preferowany, ani akceptowany przez większość, to jednak może przynieść jednostce szczęście. Wspomnieć należy chociażby o Diogenesie, który realizując w praktyce idee cynizmu, porzucił dom, rodzinę, pracę i wszelkie dobra materialne, które miał, by w słynnej „beczce” (dziś powiedzielibyśmy: „na ulicy") wieść satysfakcjonujące go życie. Musimy mieć na uwadze, że drogi do szczęścia i spełnienia są bardzo różne.

Rozważania z zakresu etyki "jakości życia” ukazują, jak płynne i subiektywne jest pojęcie „jakości”. Odnieśmy się do problemu tzw. „bezdomności z wyboru”. Można uznać, że tego typu bezdomność jest utrwalanym społecznie mitem, chociażby ze względu na znikomy procent ludzi decydujących się na taką bezdomność. Rozważając jednak czysto hipotetycznie (przy uwzględnieniu konieczności poszanowania praw mniejszości w demokratycznych państwach), zasadne wydaje się pytanie: czy w takich przypadkach możliwe jest osiągnięcie zakładanego celu, tj. zapewnienie bezdomnemu godnego życia za pomocą „przymusowych rozwiązań"? Nie wydaje się to chyba realne. Można prognozować, że ów bezdomny, nawet gdyby zapewniono mu mieszkanie, i tak powró- ciłby do dawnego stylu życia. Ingerencja w prywatność mogłaby być przez niego zasadnie odebrana jako naruszenie jego subiektywnej godności, tzw. „godności osobistej”. Uwzględnianie w praktyce owej godności mogłoby się stać - w wielu przypadkach "zasłoną" dającą usprawiedliwienie do niepodejmowania przez państwo odpowiednich działań w zakresie przeciwdziałania bezdomności. Obawy przed jej naruszeniem mogłyby legitymizować bierność władzy.

Niewątpliwie należy starać się odróżniać te sytuacje, w których należy pomagać, od takich, w których pomagać się nie powinno. Nieść pomoc trzeba niewątpliwie tam, gdzie w grę wchodzą żywotne potrzeby. Moralny obowiązek pomocy mamy wtedy, jeśli potrzebuje jej ktoś, kto nie może uzyskać tego, na czym bardzo mu zależy i do czego ma pełne prawo. Potrzeba pomocy musi być wyraźna i wynikać z bezradności zainteresowanego. Forma pomocy lub jej rozmiar powinny być ściśle określone. Zainteresowany pomocą nie może wymagać jej w nieograniczonym czasie. Warto zwrócić uwagę na fakt, że nieraz osoba potrzebująca pomocy może nawet o tym nie wiedzieć. Natomiast z drugiej strony ten, kto pragnie jej udzielić może nie zdawać sobie sprawy na czym polega skuteczna pomoc. Obowiązek moralny udzielania pomocy obejmuje przede wszystkim ludzi bliskich (rodzina, przyjaciele) oraz ludzi związanych specjalnymi zobowiązaniami (opieka, obietnica, władza). Granice moralnego obowiązku pomagania określone zostają przez normy moralne, obyczajowe, religijne i prawne. [Hołówka, 1978, s. 38 i nast.].

\section{O istocie pomocy społecznej w świetle prawa polskiego}

W rozważaniach doktrynalnych spotyka się liczne definicje pomocy społecznej. Ich treści uzależnione są od tego, przez kogo były one formułowane, kiedy i dla jakich celów [Staręga-Piasek, 1986, s. 6; Czajka, 1985, s. 15]. 
Liczne słowniki, leksykony i encyklopedie prawa zawierają różnorodne deskryptywne definicje [np. Hołyst, Smoktunowicz, 2005, s. 667; Kalina-Prasznic, 1999, s. 512-514].

Należy mieć na uwadze, że pomoc społeczna jest jedną z najstarszych i zarazem najbardziej istotnych instytucji polityki społecznej. W jej ewolucji wyróżnić można kilka etapów. Szczególnie ważna okazuje się dobroczynność prywatna, dobroczynność publiczna, opieka społeczna oraz pomoc społeczna [Miruć, 2006, s. 20-42].

$\mathrm{Na}$ gruncie prawa polskiego pomoc społeczna stanowi niezbędną i integralną część prawa zabezpieczenia społecznego. Posiada ona charakter subsydiarny w odniesieniu do ubezpieczeń społecznych i zaopatrzenia społecznego. Obejmuje bowiem przypadki, w których nie ma możliwości wypłaty świadczeń z tychże tytułów. Może je ponadto uzupełniać [Mincer, 1983, s. 80].

Pomoc społeczna jest czymś w rodzaju „koła ratunkowego". Zajmuje się sytuacjami, w których występują niedostatki systemu ubezpieczenia i zaopatrzenia społecznego. Wiąże się przykładowo z przypadkami niskich rent, emerytur, zasiłków dla bezrobotnych. Dotyczy negatywnych skutków polityki społecznej państwa (np.: alkoholizm, narkomania itp.), a także kumulacji społecznych dysfunkcji (np.: choroba, starość, bezrobocie, bezdomność etc).

Wyróżnić można trzy zakresy działania pomocy społecznej: 1) profilaktykę (tj. zapobieganie powstawaniu trudnych sytuacji życiowych); 2) diagnozę (wyrażającą się w trafnym rozeznaniu potrzeb społeczeństwa); a także: 3) terapię (możliwą do realizacji przy pomocy profesjonalnej kadry, środków finansowych i odpowiedniej infrastruktury technicznej).

Pomoc społeczna jako instytucja życia społecznego stanowi jednocześnie bardzo ważną instytucję prawną [Mincer, 1983, s. 83 i nast.]. Niezmiernie istotne są w niej cele, funkcje, normy oraz wartości. Szczególne zna- czenie ma zwłaszcza godność osobowa i osobista, sprawiedliwość oraz wolność [Brozi, 1983, s. 73].

Głównym celem pomocy społecznej stało się zarówno zaspakajanie niezbędnych potrzeb, jak również zapobieganie trudnym sytuacjom życiowym. Nadrzędny i podstawowy cel takiej pomocy zawarty został w art. 2 ustawy z dnia 12 marca 2004 r. o pomocy społecznej ${ }^{1}$. Podkreśla się w niej konieczność przezwyciężania trudnych sytuacji dotyczących osób (rodzin), które nie są w stanie samodzielnie pokonać pojawiających się w ich życiu trudności.

Ogólnym celem pomocy społecznej zawsze był i będzie tzw. „dobrostan ludzi”. Realizacji takiego założenia mają służyć odpowiednie cele operacyjne - zarówno główne, jak i szczegółowe: „Cel główny (...), zawsze dotyczyć będzie podstawowego zagadnienia, jakim jest godność człowieka (...). W przypadku celów szczegółowych mogą one ulegać pewnym korektom, np. poprzez zdefiniowanie nowych, które dotychczas nie występowały (...). Uzależnione jest to przede wszystkim od aktualnej sytuacji społeczno-gospodarczej państwa oraz priorytetów prezentowanych przez opcje sprawujące władzę" [Szcześniak, 2013, s. 92]. Jak słusznie stwierdza H. Szurgacz, pomoc powinna działać w sytuacjach zagrożenia egzystencji oraz obniżenia jakości życia poniżej społecznie akceptowanego minimum [Szurgacz, 1992, s. 75].

Pomoc społeczna wypełnia różnorakie funkcje [Kaźmierczak, Łuczyńska, 1998, s. 82-85]. R. Titmuss wskazuje, że najważniejsze pośród nich to: częściowa kompensacja szkód spowodowana przez społeczeństwo (np. bezrobocie); częściowa kompensacja upośledzenia (np. niepełnosprawność); ochrona społeczeństwa (np. usługi psychiatryczne); bezpośredni lub odsunięty w czasie wzrost indywidualnego dobrobytu; inwestowanie

T.j. Dz.U. z 2018 r. poz. 650, 700 z późn. zm., dalej: u.p.s. 
w przyszłą jednostkową lub grupową korzyść. Rolą pomocy społecznej jest więc budowanie poczucia bezpieczeństwa socjalnego, poprzez wypełnianie niedostatków systemu emerytalno-rentowego, systemu wynagrodzeń, zasiłków dla bezrobotnych oraz innych systemów zabezpieczenia społecznego.

Pomoc społeczna w prawie może być określana w szerokim i wąskim ujęciu [Nitecki, 2013, s. 97]. W ujęciu sensu largo stanowią ją różne formy wsparcia świadczone osobom potrzebującym głównie poprzez instytucje publiczne. Regulacje prawne dotyczą m.in.: wsparcia niepełnosprawnych, zasiłków rodzinnych, problematyki zatrudnienia, walki z uzależnieniami, ochrony zdrowia psychicznego, ochrony mieszkania, renty socjalnej. Natomiast pomoc społeczna sensu stricto unormowana została w u.p.s.

Mając na uwadze rozwiązania u.p.s. pomoc społeczna to pomoc organizowana przez organy administracji rządowej i samorządowej we współpracy z innymi podmiotami (np. kościołami, organizacjami społecznymi i pozarządowymi). Jest ona realizowana w formie zróżnicowanych i zmiennych w czasie świadczeń (zarówno o charakterze materialnym, jak i niematerialnym), które są finansowane ze źródeł publicznych. Istotne staje się przy tym uwzględnienie zasady pomocniczości i indywidualizacji. Uzasadniają one udzielenie takiej pomocy szczególnie trudną sytuacją życiową osób (rodzin). Celem pomocy jest zaspakajanie niezbędnych potrzeb życiowych oraz umożliwienie bytowania w warunkach odpowiadających godności człowieka. Istotną konsekwencją jest zapobieganie potencjalnym dysfunkcjom.

Określenie istoty pomocy społecznej w Polsce wymaga wskazania jeszcze innych jej podstawowych cech. Podkreślić należy, że rozbudowana regulacja prawna dotycząca powyższego zagadnienia ma charakter administracyjnoprawny, uzupełniany jednak często specyfiką cywilnoprawną. Ponadto pomoc społeczną cechuje indywidualizacja i fakultatywność świadczeń przyznawanych zarówno w drodze decyzji administracyjnej, jak umowy cywilnoprawnej, lub działań faktycznych wynikających wprost z norm zadaniowych.

Funkcjonowanie pomocy społecznej można ująć $\mathrm{w}$ ramy systemu warunkowanego różnorodnością współistniejących ze sobą świadczeń. Widoczne staje się przy tym także zróżnicowanie instytucjonalne. Aparat administrujący pomocą społeczną składa się bowiem nie tylko z organów administracji publicznej, ale również z podmiotów niepublicznych i wyspecjalizowanej służby (z pracownikami socjalnymi i asystentami rodziny na czele).

Zakres i struktura pomocy społecznej jest niewątpliwie pochodną wielu czynników. Zauważyć przy tym należy, że sens znaczeniowy pojęcia „pomocy społecznej” w polskich regulacjach prawnych ma zdecydowanie szeroki zakres. Pojęcie to rozumiane bywa szerzej niż np. w Unii Europejskiej. Pokrywa się na ogół z pojęciem tzw. "ochrony socjalnej”. Zauważalny semantyczny dysonans wynika zapewne ze zróżnicowanego podziału materii dotyczącej pomocy społecznej w prawie międzynarodowym i w prawie Unii Europejskiej. W powyższych regulacjach prawnych funkcjonuje wyraźny podział na: „zabezpieczenie społeczne" i „pomoc społeczną”.

\section{Godność jako podstawa "dobrego administrowania"}

Godność stała się fundamentem wyznaczającym kierunki prawotwórstwa. Słuszna jest teza J. Bocia podkreślającego, że prawo nie powinno być tworzone dla "samego siebie". Nie powinno być również stanowione wyłącznie dla „administracji”, która ma służyć przede wszystkim człowiekowi oraz ludzkim wspólnotom [Boć, 2016, s. 73 i nast.]. Godność jako przyrodzone, naturalne i niezbywalne dobro związane z istotą człowieczeństwa powinna więc podlegać szczególnej ochro- 
nie [Michalska-Badziak, 2009, s. 472-482]. Idea godności odgrywa ważną rolę także z punktu widzenia rodzaju i zakresu udzielanych świadczeń. Organy pomocy społecznej muszą ustalać wysokość i formę przyznanego świadczenia zgodnie z nią ${ }^{2}$.

Na gruncie prawa do pomocy społecznej godność człowieka wiąże się z zapewnieniem bytowania świadczeniobiorcom w godnych warunkach. Zakres tej ochrony ulega zmianom i jest efektem przyjętej przez państwo polityki społecznej oraz stanu finansów publicznych. Należy zauważyć, że ochrona godności osób i rodzin jest jedną z przewodnich myśli wyrażonych w u.p.s. Niemniej niektóre regulacje trudno pogodzić $z$ tą fundamentalną wartością. Można mieć wątpliwości, czy minimalna wysokość zasiłku stałego lub zasiłku okresowego (dla rodziny) w kwocie kilkudziesięciu złotych miesięcznie jest wyrazem poszanowania ludzkiej godności.

Tym niemniej można stwierdzić, że wiele postanowień zawartych w u.p.s. nawiązuje do idei godności. Dotyczą one m.in. konieczności wspierania poprzez społeczną pomoc osób (rodzin) w celu zaspokojenia ich niezbędnych potrzeb i umożliwienia im życia w odpowiednich warunkach (art. 3. ust. 1 u.p.s.). Również w pracy socjalnej należy stosować takie metody i techniki, które gwarantują poszanowanie godności osoby oraz jej prawa do samostanowienia (art. 45 ust. 3 u.p.s). Podobnie jest, jeśli chodzi o funkcjonowanie domów pomocy społecznej, zakres oraz poziom usług tam świadczonych. Godność, wolność, intymność oraz poczucie bezpieczeństwa mieszkańca takiego domu to absolutne priorytety (art. 55 ust. 2 u.p.s.).

Pojęcie godności występuje w wielu ustawowych aktach prawnych jako forma gwarancji respektowania podstawowych praw człowieka wyrażonych w Konstytucji RP. Uznaje się, że prawo winno pełnić rolę

Wyrok TKz dnia 23 marca 1999 r., K2/ 98, OTK 1998, nr 4, poz. 74. wzorca (ideału) realizującego normatywny ideał godności [Zięba-Załucka, 2001, s. 407]. Współczesność wyraźnie ukazuje jednak, jak dynamiczne i zarazem "kruche" jest to pojęcie [Chauvin, 2014 s. 264]. W obliczu wyzwań XXI w. (np.: globalizacja, migracje, terroryzm, postęp naukowy, coraz bardziej złożone stosunki ekonomiczne) okazuje się, że poszerzeniu ulega sfera wykluczenia społecznego wynikającego chociażby z ubóstwa czy bezdomności.

\section{Bezpieczeństwo socjalne w kontekście rozważań na temat pomocy społecznej}

Rolą administracji pomocy społecznej jest stwarzanie poczucia bezpieczeństwa socjalnego, pomoc w tworzeniu godnych warunków życia oraz wspomaganie nieporadnych osób i rodzin [Miruć, 2014, s. 153-166]. Istota fundamentalnych wartości moralnych (zwłaszcza godności, sprawiedliwości i autonomii) przejawia się w tym, iż pozwalają one na zauważenie złożoności relacji zachodzących pomiędzy poszczególnymi uczestnikami skomplikowanego procesu udzielania świadczeń z obszaru pomocy społecznej. Zarówno godność, jak też sprawiedliwość oraz jednostkowa autonomia wpływają na sytuację prawną, jak i faktyczną osoby (lub rodziny) korzystającej ze świadczeń pomocy społecznej. Organy pomocy społecznej, posiłkujące się tak nieostrymi pojęciami jak "godność”, „autonomia” czy "sprawiedliwość", dysponują zwiększonym zakresem uznaniowości przy podejmowaniu rozstrzygnięć. Może to wywoływać zarówno pozytywne, jak i negatywne konsekwencje dla podmiotów prawa ubiegających się o świadczenia.

Nie należy wykluczać, iż w praktyce mogą pojawiać się zagrożenia polegające na wykorzystywaniu przez administrację pomocy społecznej pozycji dominującej i traktowania osób (rodzin) korzystających z pomocy 
w sposób, który naruszałby ich przyrodzoną i niezbywalną godność, reguły sprawiedliwości społecznej lub jednostkowej autonomii.

Obok wartości pozytywnych przy stosowaniu prawa do pomocy społecznej mogą pojawiać się tzw. „antywartości”, rozumiane jako zróżnicowane formy osłabiania sytuacji jednostki wobec władzy administracyjnej, podważające sens tego prawa. W pomocy społecznej jako przykłady wartości ujemnych realizowanych w praktyce można wskazać chociażby: nadmierny formalizm proceduralny, niepewność prawa w tym zakresie, niemoc władztwa zakładowego. Wszystko to skutkuje m.in. osłabieniem pozycji jednostki i rodziny wobec organów administracji pomocy społecznej, a przecież to właśnie jednostka powinna być głównym beneficjentem prawa administracyjnego w omawianym zakresie. Fundamentalne wartości zapisane w prawie (takie jak np.: godność, sprawiedliwość czy autonomia jednostki) nie są więc w pełni realizowane.

\section{Bezdomność jako przesłanka do udzielania pomocy społecznej w polskim systemie prawnym}

Jedną z istotnych przesłanek udzielania pomocy społecznej w polskim systemie prawnym jest bezdomność. W 2000 r. w u.p.s. pojawiła się definicja osoby bezdomnej. Jest nią osoba, która nie zamieszkuje w lokalu mieszkalnym (w rozumieniu przepisów o ochronie praw lokatorów i mieszkaniowym zasobie gminy) i nigdzie nie jest zameldowana na pobyt stały (na podstawie przepisów o ewidencji ludności). Do takiej kategorii przynależą ponadto osoby, które nie zamieszkują w lokalu mieszkalnym, a także zameldowane na pobyt stały w lokalu, w którym nie ma możliwości zamieszkania (art. 6 pkt 8 u.p.s.). Można ocenić, że przyjęta w ustawie definicja jest dość sztuczna. Wydaje się ponadto możliwa do wykorzystywana wyłącznie na gruncie u.p.s. [Nitecki, 2013, s. 97]. Nie obejmuje ona wszystkich bezdomnych. Bezdomność może wynikać z różnych innych przyczyn niż te, które wynikają ze wspomnianej wyżej ustawy. Wspomnieć należy chociażby o osobach, które przez dłuższy czas przebywały w szpitalu czy w zakładzie karnym, zaś ich budynek mieszkalny został wyburzony. Nie należy ponadto pomijać sytuacji, w których człowiek zostaje wymeldowany "donikąd". Ponadto uwzględnić trzeba, że bezdomność, choć bardzo rzadko, to jednak może być świadomym wyborem stylu życia (Sierpowska, 2001, s. 85-86). Podkreślić warto, iż uznanie danej osoby za "bezdomną" nie jest uzależnione od motywów jej postępowania. Wynika ze spełnienia wymogów przewidzianych w u.p.s.

Bezdomność stała się niewątpliwie zjawiskiem społecznym wymagającym odpowiedniej polityki i strategii działania władzy publicznej. Z perspektywy polityki społecznej określana jest jako względnie trwała sytuacja człowieka nieposiadającego własnego mieszkania albo w ogóle pozbawionego dachu nad głową [Michalska-Badziak, 2004, s. 37-38; Kaźmierczak, Łuczyńska, 1998, s. 65 i nast.]. To właśnie w przypadkach bezdomności kluczowe okazuje się uwzględnianie godności (zarówno osobowej, jak i osobistej), która ma istotny wpływ na indywidualne rozstrzygnięcia podejmowane przez organy administracji publicznej, jak również sądy [Lipowicz, 2013, s. 42-43]. Konieczność jej dostrzeżenia staje się obecnie absolutnie niepodważalna; tym bardziej, że możliwość naruszenia godności wzrasta, chociażby z tego powodu, że pozycja jednostki wobec administracji jest $z$ reguły słabsza.

\section{Podsumowanie}

Aksjologiczne i prawne ujęcie pomocy społecznej ukazuje zarówno wieloznaczność, jak i niejasność tego pojęcia. Jest to szczególnie wyraźne w kontekście godności i autonomii osoby bezdomnej. „Pomaganie” 
uznane zostało za pozytywny i powszechnie oczekiwany element współczesnego świata wartości, zaś moralny obowiązek udzielania pomocy obejmuje przede wszystkim ludzi bliskich oraz władzę. Jednak nie każda pomoc może być traktowana jako działanie "dobre”. Granice moralnego obowiązku pomagania określone są przez normy moralne, obyczajowe, religijne i prawne. $W$ pewnych sytuacjach nie należy pomagać. Dotyczy to tych przypadków, kiedy pomoc kłóci się z ideą godności osobowej przynależnej każdemu człowiekowi z mocy prawa (dotyczy to także osób bezdomnych). Godność człowieka nie powinna być naruszona poprzez nadmierne, nieuzasadnione ingerencje $w$ jego prawo do prywatności oraz prawo do decydowania o własnym życiu. W liberalnym ujęciu nikomu nie można zabronić uprawiania preferowanego stylu życia, który mieści się w ramach

\section{Literatura}

Boć J. (2016). „Esej o generalnej policji administracyjnej", w: D. R. Kijowski, A. Miruć, A. Budnik (red.), Racjonalny ustawodawca. Racjonalna administracja (s. 73-80). Białystok: Temida 2.

Brozi K.J. (1983). Antropologia funkcjonowania Bronisława Malinowskiego. Lublin: Wydawnictwo Lubelskie.

Chauvin T. (2014). Homo luridicus. Człowiek jako podmiot prawa publicznego. Warszawa: Wydawnictwo C.H. Beck.

Czajka S. (1985). „Uwagi do przyszłej ustawy o pomocy społecznej", Praca i Zabezpieczenie Społeczne, 1985, nr 4-5.

Hołówka J. (1978). „O pomocy w potrzebie”, Etyka, nr 16, s. 37-49.

Hołyst B., Smoktunowicz E. (red.) (2005). Wielka Encyklopedia Prawa, wydanie II. Warszawa: Wydawnictwo Prawo i Praktyka Gospodarcza.

Kalina-Prasznic U. (red.) (1999). Encyklopedia prawa. Warszawa: Wydawnictwo C.H. Beck.

Kant I. (1953). Uzasadnienie metafizyki moralności. Warszawa: Państwowe Wydawnictwo Naukowe.

Kaźmierczak T., Łuczyńska M. (1998). Wprowadzenie do pomocy społecznej. Wybrane zagadnienia. Katowice: Wydawnictwo Śląsk.

Księga aforyzmów (2008). Warszawa: Buchmann. indyferencji prawnej Władza ma szanować nie tylko godność osobową człowieka, ale również jego godność osobistą. Tym samym, nie można ograniczać autonomii osoby bezdomnej, zmuszając ją chociażby do zamieszkania w lokalu socjalnym w imię zapewnienia jej "godnego życia”. I chociaż należałoby zgodzić się z poglądem, że problem „bezdomności z wyboru" jest właściwie mitem, to jednak warto się nad nim pochylić. Pomimo statystyk, które niezbicie dowodzą, że bezdomność jako wybierany styl egzystencji nie jest popularna, należy uwzględnić tego typu mniejszość w demokratycznym państwie prawa; wszak współczesna, liberalna demokracja to rządy większości przy poszanowaniu praw mniejszości. „Uszczęśliwianie” odbiorców pomocy społecznej wbrew ich woli nie zasługuje z pewnością na pozytywną ocenę etyczną.

Kusak L. (2012) . „O niejednoznaczności idei pomocy”, Prakseologia, nr 153, s. 11-30.

Lipowicz I. (2013). O mąre prawo i wrażliwe państwo. Warszawa: Biuro Rzecznika Praw Obywatelskich.

Michalska-Badziak R. (2004). "Bezdomność jako przesłanka udzielania świadczeń z pomocy społecznej", Casus, nr 34, s. 37-41.

Michalska-Badziak R. (2009). "Godność człowieka w prawie pomocy społecznej", w: J. Supernat (red.), Między tradycja a przyszłościq w nauce prawa administracyjnego. Księga jubileuszowa dedykowana Profesorowi Janowi Bociowi. Wrocław: Wydawnictwo Uniwersytetu Wrocławskiego.

Mincer M. (1983). „Pomoc społeczna jako instytucja prawna", Nowe Prawo, nr 1, s. 80-83.

Miruć A. (2006). "O istocie pomocy społecznej”, Administracja: teoria, dydaktyka, praktyka, nr 4 (5), s. 20-42.

Miruć A. (2014). „Bezpieczeństwo socjalne a realizacja sprawiedliwości i godności w pomocy społecznej", w: M. Wożniak, E. Pierzchała (red.), Dobra publiczne w administracji. Toruń: Wydawnictwo TNOiK.

Miruć A. (2017). "Godność człowieka jako wyznacznik prawa administracyjnego stanowionego na szczeblu centralnym", w: J. Zimmermann (red.), Aksjologia prawa administracyjnego, tom 1. Warszawa: Wydawnictwo Wolters Kluwer.

Nietzsche F. (2003). Antychryst. Próba krytyki chrześcijaństwa. Kraków: Wydawnictwo Zielona Sowa. 
Nietzsche F. (2010). Poza dobrem i złem. Kraków: Wydawnictwo Vis-a-Vis Etiuda.

Nitecki S. (2013). Komentarz do ustawy o pomocy społecznej. Wrocław: Wydawnictwo Gaskor.

Pavia M.-L. (2001). "Odkrycie godności osoby ludzkiej we Francji", w: K. Complak (red.), Godność człowieka jako kategoria prawna (opracowania i materiały). Wrocław: Wydawnictwo Uniwersytetu Wrocławskiego.

Raz J. (2000). Autorytet prawa. Eseje o prawie i moralności. Warszawa: Dom Wydawniczy ABC.

Sadowski M. (2007). „Godność człowieka - aksjologiczna podstawa państwa i prawa", Wrocławskie Studia Erazmiańskie, s. 8-28.

Sierpowska I. (2001). „Sytuacja prawna osoby bezdomnej w Polsce", Praca Socjalna, nr 3, s. 85-105.

Staręga-Piasek J. (1986). "Pojęcie pomocy społecznej", Praca Socjalna, nr 1.
Szcześniak P. (2013). System pomocy społecznej w krajach Unii Europejskiej na przykładzie Polski i Niemiec. Opole: Wydawnictwo Naukowe Scriptorium.

Szurgacz H. (1992). Wstęp do prawa pomocy społecznej. Wrocław: Wydawnictwo Uniwersytetu Wrocławskiego.

Ustawa z dnia 12 marca 2004 r. o pomocy społecznej, t.j. Dz.U. z 2018 r. poz. 650, 700 z późn. zm.

Wilson E.O. (1998). O naturze ludzkiej. Poznań: Wydawnictwo Zysk i S-ka.

Wyrok TK z dnia 23 marca 1999 r., K 2/ 98, OTK 1998, nr 4, poz. 74

Zięba-Załucka H. (2001). „Godność człowieka i jej ochrona wobec działań administracji publicznej", w: E. Ura (red.), Jednostka wobec działań administracji publicznej. Rzeszów: Mitel.

\section{The concept of "social assistance" in the context of the dignity and autonomy of the homeless (philosophical and legal aspects)}

Summary: Social assistance is an institution of social life, whose proper functioning is determined not only by law enforcement, but also by norms belonging to diverse non-legal systems (especially the moral system). The purpose of this paper is to analyze the concept of "social assistance” in the context of the dignity and autonomy of the homeless, considered both from the axiological and legal point of view. In this regard, we use the dogmatic method. The philosophical perspective shows that the notion of "assistance" is ambiguous and does not always entail a positive axiological charge. From the legal approach, the basic premises of "good administration" and the actual provision of social welfare to those in need (including the homeless) are: personal and individual dignity, related to the obligation to respect human autonomy. Social assistance that does not take these values into account cannot be considered as a "good practice".

Keywords: homeless, dignity, autonomy, axiology, social assistance.

\section{Prawa autorskie i licencja / Copyright and License}

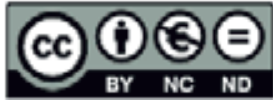

Artykuł opublikowano na licencji Creative Commons Uznanie autorstwa - Użycie niekomercyjne - Bez utworów zależnych 3.0 Polska http://creativecommons.org/licenses/by-nc-nd/3.0/pl/

This article is published under the terms of the Creative Commons Attribution - NonCommercial - NoDerivs (CC BY-NGND 3.0) License http://creativecommons.org/licenses/by-nc-nd/3.0/ 